\title{
Unzipping Your Genes: A Fashionable Tutorial in Gene Expression
}

\author{
Kristina Lackey, Barbara Waring, Tori Tucker, and Debra Mauzy-Melitz
}

\author{
University of California-Irvine, Department of Developmental and Cell Biology, School of \\ Biological Sciences, 2011 Biological Sciences III, Irvine CA USA 92697 \\ (lackeyk@uci.edu; waringb@uci.edu; dmauzyme@uci.edu)
}

\begin{abstract}
Transcription is a very detailed process that is essential for understanding the basis of gene expression However, undergraduate students are taught this concept during introductory biology courses and are rarely given the opportunity or time to diagram this process in a step-by-step manner. Students reconstructed the initiation, elongation, and termination steps of eukaryotic transcription, using a physical model. Briefly, students determined the stages of transcription with jean material and cloth pieces that symbolize important components of the transcription machinery. In this workshop, participants worked together to outline the process of transcription in small groups and presented their model to others. This module can be used to compare eukaryotic and prokaryotic transcription. Furthermore, this versatile activity be used to simulate errors in transcription that result in disease and elucidate the mechanisms of genetic engineering technologies
\end{abstract}

Keywords: Transcription modeling

\section{Mission, Review Process \& Disclaimer}

The Association for Biology Laboratory Education (ABLE) was founded in 1979 to promote information exchange among university and college educators actively concerned with teaching biology in a laboratory setting. The focus of ABLE is to improve the undergraduate biology laboratory experience by promoting the development and dissemination of interesting, innovative, and reliable laboratory exercises. For more information about ABLE, please visit http://www.ableweb.org/.

Advances in Biology Laboratory Education is the peer-reviewed publication of the conference of the Association for Biology Laboratory Education. Published articles and extended abstracts are evaluated and selected by a committee prior to presentation at the conference, peer-reviewed by participants at the conference, and edited by members of the ABLE Editorial Board. Published abstracts are evaluated and selected by a committee prior to presentation at the conference.

\section{Citing This Article}

Lackey K, Waring B, Tucker T, Mauzy-Melitz D. 2020. Unzipping your genes: a fashionable tutorial in gene expression. Article 40 In: McMahon K, editor. Advances in biology laboratory education. Volume 41. Publication of the 41st Conference of the Association for Biology Laboratory Education (ABLE). https://doi.org/10.37590/able.v41.abs40

Compilation (C) 2020 by the Association for Biology Laboratory Education, ISBN 1-890444-17-0. All rights reserved. No part of this publication may be reproduced, stored in a retrieval system, or transmitted, in any form or by any means, electronic, mechanical, photocopying, recording, or otherwise, without the prior written permission of the copyright owner.

ABLE strongly encourages individuals to use the exercises in this volume in their teaching program. If this exercise is used solely at one's own institution with no intent for profit, it is excluded from the preceding copyright restriction, unless otherwise noted on the copyright notice of the individual chapter in this volume. Proper credit to this publication must be included in your laboratory outline for each use; a sample citation is given above. 